\title{
ЛЕКСЕМА ГЕНИЙ В СЛОВАРЯХ РУССКОГО ЯЗЬКА, ХУДОЖЕСТВЕННЫХ И ПУБЛИЦИСТИЧЕСКИХ ТЕКСТАХ: ПЕРВЫЕ ФИКСАЦИИ И СЛОВОУПОТРЕБЛЕНИЯ
}

В статье рассматриваются истоки интерпретаций концепта 'гений' русским культурным сознанием. На обширном материале словарей русского языка XVIII-XX вB анализируются первые фиксации лексемы гений, систематизируются ее толкования.

Высказывается наблюдение о том, что древнегре-

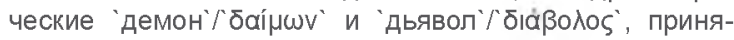
тые русским православием в значении 'нечистый дух', 'падший ангел', 'нечистая сила', 'злой дух', получили древнерусские и старославянские аналоги и воспринимались исключительно через призму новозаветной борьбы и победы Иисуса Христа, а затем и христиан над дьяволом, в то время как в римском языческом аналоге - гении - не было острой необходимости. Указывается, что на рубеже XIX-XX вB. в русской языковой картине мира эти понятия воспринимались как синонимичные, появившийся же в русском языке в XVIII в. (причем, не непосредственно через латынь) концепт гений имел уже значение имманентного свойства человеческой природы и начал свое отдельное существование, зачастую принимая функцию слова-номинанта и обрастая собственными словами-вербализаторами, ассоциативно-семантическими полями

На примерах художественных текстов XIX в. рассматриваются варианты словоупотребления данной лексемы, доказывается образование концепта 'гений' появление новых семантических полей последнего как свидетельство принятия его российским культурным сознанием.

Делается вывод о том, что мифологема 'гений' была принята российским культурным сознанием опосредованно - через античность - и потому в исконном смысле существовала в переводных латинских текстах, в заимствованных мифологических образах и персонажах или использовалась в качестве метафоры; актуально же в русскую языковую картину мира вошло толкование гения как самобытного творческого дара в человеке, воплощения высших творческих способностей, вершины человеческого развития, т.е. на стадии идеологизации и ценностной нагруженности понятия.

Путем анализа словоупотреблений 'гений' и 'дух' в XVIII-XIX вB. доказывается, что значения 'творческий дар в человеке' и 'человек, обладающий творческим даром`, вытеснили изначальную внутреннюю семантику лексемы гений.

Отмечается, что появление новых семантических полей данного концепта - свидетельство значительных трансформаций национальной, научной и художественной картины мира в отечественном культурном пространстве.

Ключевые слова: лексема, лексическая форма, словарь, гений, толкование, семантическое поле, культурное сознание.

\section{F. K. Besolova}

\section{THE LEXEME "GENIUS” IN RUSSIAN DICTIONARIES, FICTION AND PUBLICISTIC TEXTS: FIRST CASES OF USE AND WORD USAGE}

The article discusses the origins of interpretations of the concept "genius" by Russian cultural consciousness. The first cases of use of the lexeme "genius" are analyzed, its interpretations are systematized on the extensive material of dictionaries of the Russian language of XVIII-XX centuries

It is observed that the ancient Greek "demon" I סai

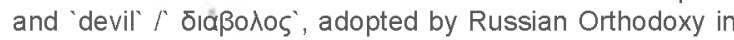
the meaning of "unclean spirit", "fallen angel", "evil spirit", "evil spirit", received the Old Russian and the Old Slavonic analogues and were perceived exclusively through the prism of the New Testament struggle and the victory of Jesus Christ, and then of Christians over the devil, while in the Roman pagan analogue - genius - there was no urgent need. It is indicated that at the turn of the $X I X-X X$ centuries in the Russian language picture of the world, these concepts were perceived as synonymous, which appeared in the Russian language in the XVIII century (and not directly through Latin) the concept of genius already had the value of the immanent property of human nature and began its separate existence, often taking on the function of a nominal word and acquiring its own verbalizers and associative semantic fields.

The examples of fiction texts of the $X \mid X$ century examine the variants of the use of the lexeme "genius", the formation of the concept of genius is proved, the emergence of new semantic fields as evidence of its acceptance by Russian cultural consciousness.

By analyzing the phrases "genius" and "spirit" in the XVIII-XIX centuries proves that the values of "creative gift in man" and "man possessing creative gift" have superseded the original inner semantics of the lexeme "genius". 
It is noted that the emergence of new semantic fields of this concept is the evidence of significant transformations of the national, scientific and artistic picture of the world in the domestic cultural space.

Греко-римская античная культура, породив феномены «внутреннего голоса», объективизации эмоциональных всплесков, обозначила их понятиями даймон (боíf $\omega v)$ и гений (genius). Синонимичность (внутренней формы) концептов «даймон» и «гений», их генезис - одна из интернациональных проблем мировой науки. Как западные, так и российские исследователи: лингвисты, философы, религиоведы, историки античности, культурологи, литературоведы - разрабатывают ее не первое столетие, вступая в диалог с античными авторами, пытаясь осуществить, выражаясь словами А. Михайлова, «обратный перевод» древнегреческих и латинских текстов.

Учитывая, что русская светская культура, с «опозданием» включившаяся в единый европейский интеллектуальный контекст, продемонстрировала свойство "всемирной отзывчивости" и способность насыщать своим содержанием чужие формы, представляется актуальным проанализировать первые словарные фиксации и толкования лексемы гений, самые ранние ее словоупотребления в отечественной литературе и определить, сорормировали ли смысловые приращения лексемы гений одноименный концепт в русской культуре

Иными словами, задачей данной работы является определение изначального лексического значения заимствованной лексемы 'гений' (слово-номинант) и систематизация ее ассоциативно-семантических полей (слов-вербализаторов) с целью проследить процесс формирования концепта 'гений' в русской языковой картине мира и выявить возможные схождения с европейским культурным сознанием. Предполагается, что появление новых семантических полей обозначенного концепта свидетельствует о трансформациях российского культурного сознания, коррелирующихся с общеевропейскими тенденциями.

Уходя корнями в истоки европейской культуры ${ }^{1}$, концепт «гений» пронизывает мировое культурное пространство, обрастая новыми оттенками транслируемых смыслов, актуальных для каждой новой эпохи. В результате первоначальное значение лексической основы, имманентно присутствуя во всех новых толкованиях, не всегда понятно носителям современного языка.

А между тем история интерпретаций концепта «гений» - свидетельство значительных трансформаций национальных, научных и художественных картин мира - как в мировом, так и в отечественном культурном пространстве. Оттолкнувшись от

${ }^{1}$ Культ даймона (бaij номорской античности зародился в период разложения общинно-родовых отношений и имеет аналоги с широко распространёнными у многих народов культами личных духов-покровителей.
Key words: lexeme, lexical form, dictionary, genius, interpretation, semantic field, cultural consciousness.

античной мифологемы прародителя рода, божественного двойника человека, врожденного дара, пройдя этап XVII-XVIII вв. в качестве фрилософрски-эстетического понятия, концепт «гений» распался в XIX в. на множество идеологем: гений как высшая способность к художественному творчеству (предромантики); художник как мистический творец мира (романтики); гениальность как избыток интеллекта (учение Шопенгауэра), гениальность как отклонение от нормы (теории гениальности Ломброзо, Нордау, Ницше) и др. Несмотря на то, что каждый автор имел в виду свое семантическое поле концепта «гений», общим для всех стало осознание гениальности как имманентного свойства личности, а не идущей извне сверхъестественной силы.

В корпусе русского языка лексемы демон, гений появились значительно позднее европейских аналогов и использовались скорее не в философрской - как в средиземноморском первоисточнике, - а в теологической сорере: в то время как древнегреческие 'демон' $/$ баl вол'Г б̆åßoภos', принятые русским православием в значении 'нечистый дух', 'падший ангел', 'нечистая сила', 'злой дух', получили древнерусские и старославянские аналоги и воспринимались исключительно через призму новозаветной борьбы и победы Иисуса Христа, а затем и христиан над дьяволом, в римском языческом аналоге -гении не было острой необходимости. И хотя еще на рубеже $X I X-X X$ вв. в русской языковой картине мира эти понятия воспринимались как синонимичные, появившийся в русском языке в XVIII в. (причем, не непосредственно через латынь; см. об этом ниже) концепт гений имел уже значение имманентного свойства человеческой природы и начал свое отдельное существование, зачастую принимая функцию слова-номинанта и обрастая собственными словами-вербализаторами, ассоциативно-семантическими полями.

Тем не менее, несмотря на закрепление в русской православной картине мира негативного содержания античного концепта демон/дений, позитивная, плодотворная ипостась языческой первоосновы концепта питала другой важнейший образ христианского учения - образ Ангела-хранителя, доброго духа. Таким образом, в российском национальном сознании, в православной и светской культуре изначально 'работают” обе ипостаси мифологемы демона/гения: злой и добрый демон, причем, первая ассоциируется с греческой основой, а вторая - с римской (демон злой дух, бес, гений - добрый дух, дух добра).

Православная традиция остается самодостаточной и не требует новых смыслов, светское же функционирование понятий демон и гений С XVIIIB. разделяет дублетные концепты и дает множество 
самостоятельных ростков, из которых в течение последующих веков развиваются идеологемы гения и синонимичных ему понятий Нового времени: выдающийся человек, необыкновенный человек, сверхчеловек и пр. При этом многочисленные идеологемы не вытеснили мифологему не только в сорере православия: во всех своих новых импликациях концепт гений не порывает тем не менее, внутренней смысловой связи с архетипической лексемой, в чем мы убедимся ниже

В русском языке слово 'гений' появилось в XVIII в., по некоторым источникам - в начале по другим - в середине века. Так, М. Фасмер и Н. М. Шанский указывают на Петровскую эпоху [28, с. 402; 30, с. 52], П. Я. Черных и А. В. Семенов - на середину XVIII в. $[29$, с. $185 ; 14$, с. 67$]$ Авторы «Словаря русского языка XVIII в.» дают следующую хронологию появления лексических форм гения: «Гений 1763, я, гениус 1717 (-ъуш 1701, -июш 1731, -июс 1763), а, гени 1724, жени 1769, неизм., м.» [22, с. 104]. А «Этимологический словарь русского языка» под ред. Н. М. Шанского указывает на источник первого русского употребления 'гения": «впервые встречается в значении 'дух в переведенной с немецкого языка в 1717 г. «Книге мирозрения» Гюйгенса (158), представляющей в свою очередь перевод с латинского языка) $[30$, с. 52$]$

Еще одно небольшое расхождение в комментариях - этимологического характера: большинство авторов словарных статей склоняется к происхождению двух первых форм - 'гениус' и 'гениуш' (от польского 'geniusz') через немецкое 'genius' (см., например: «В русском языке гениус (> гений, ср. викарий) получило современное значение (см. Словарь Нордстета 1780 г., I, 132) под влиянием немецкого Genie 'гений', заимствования через французское посредство того же латинского genius» [30, с.52]), другие ведут родословную русского слова от латинского 'genius' (от gigno>geno - 'рождаю', 'произвожу на свет', "порождаю') [4, с. 348; 29, с. 185;], третьи считают возможными оба варианта: «Лат. Genius, непоср И через пол. Geniusz, нем. Genius, фpp. gênie» [22, c. $104 ;$ см. также: 28 , с. $402 ; 14$, с. 67$]$.

В словарях русского языка XIX - начала XX вB указываются как существительное 'гений' (раннее написание - 'геній'), так и производные от него: существительное 'гениальность', прилагательное 'гениальный' ('геніяльный'), наречие 'гениально' (геніяльно') $[27$, с. 495; 4, с. 348; 24 с. $259 ; 20$, с. 58-59]. К числу первых словарей, включивших в состав русского языка слова 'гений', 'гениальность', 'гениально', помимо указанного Словаря Нордстета 1780 г., относятся словари: Гейма (1799), Яновского (1803), Соколова (1834) Академии Наук 1847 и 1892 гг [См.: 23, с. 70; 29, с. 185], «Словарь иностранных слов, употребительных в русской литературе» (1861) [21], «Толковый словарь живого великорусского языка» В. И. Даля (1862) [4], «Объяснение 30000 иностранных слов, вошедших в употребление в русский язык, с означением их корней» А. Д. Михель- сона (1866) [11], «Словарь церковно-славянского и русского языка», составленный ІІ отделением Императорской Академии Наук (1847) [24], «Словарь иностранных слов (60000 вошедших в употребление в русском языке с обозначением их корней)» Бурдона и Михельсона (1880) [19] и др.

На рубеже XIX-XX вв., помимо известной энциклопедии Ф. А. Брокгауза и И. А. Ефрона (18901907) [2], лексеме 'гений' посвятили словарные статьи: М. 3-ский («Словарь иностранных слов, наиболее употребительных в русском языке», 1891) [20]; М. Корш («Краткий словарь мифологии и древностей», 1894) [6]; Ф. Н. Берг («Словарь иностранных слов, вошедших в состав русского языка», 1901) [16]; Ф. Павленков («Словарь иностранных слов, вошедших в состав русского языка», 1907) [17]; М. Попов («Полный словарь иностранных слов, вошедших в употребление в русском языке», 1907) [12]; А. Чудинов («Словарь иностранных слов, вошедших в состав русского языка», 1910) [18]; Н. Смирнов («Западное влияние на русский язык в Петровскую эпоху», 1910) [26] и др

В большинстве названных словарей исконное значение лексемы 'гений: 'незримый добрый или злой дух', 'дух-покровитель человека, рода, местности', 'иррациональное вдохновение, божественное наитие (иными словами, мифологема гения) - стоит не на первой позиции, а если и начинает список значений, то упоминается как мифическое и переносное: «добрый дух» [19 с. 216], «дух добра» $[21$, с. 19]. Толкуется же ставшая к этому времени философско-эстетическим понятием лексема прежде всего как 1) свойство человеческой природы: “чрезвычайные умственные способности или дарования' $[11$, с. 164]; «выспренний, творческий ум; высокая природная способность» [24, с. 259]; «сила, которая создает в какой-нибудь отрасли науки или искусства что-либо выходящее из обыкновенного ряда» $[20$, с. 59$]$; «необыкновенное, поражающее дарование» $[16$, с.147]; «врожденная способность к творчеству в области изящных искусств» $[21$, с. 9] и как 2) человек-носитель этих свойств: «лицо, наиболее одаренное природой со стороны умственных и духовных способностей» $[12$, с. 123] «гениальный человек» [22, с. 104].

Исключением являются «Толковый словарь живого великорусского языка» В. Даля, «Энциклопедический словарь» Ф. А. Брокгауза и И. А. Ефрона и «Краткий словарь мифологии и древностей» М. Корша: Даль указывает первым из трех значений латинское 'незримый, бесплотный дух, добрый или злой; дух-покровитель человека, добрый или злой' $[4$, с. 348], Брокгауз и Эфрон начинают статью с внутренней формы концепта: «1) у древних римлян бог покровитель, у каждого человека от самого его рождения и сопровождающий его повсюду, как второе «я». Также дух родоначальника, которому воздавалось религиозное почитание. 2) Добрый или злой дух» [2, с. 337338]. Но это вызвано, на наш взгляд, скорее не градацией по актуальности словоупотребления, 
а функциональными установками изданий - универсальностью и энциклопедичностью, требующими, прежде всего, указания этимологических корней. Задача словаря М. Корша - ввести читателя в картину мира античности, дать перевод понятий, необходимых для усвоения греко-римской культуры, и потому он дает исключительно культурно-историческое толкование гения: «Дух, оживляющий известное лицо, место и т.д. и соответствовавший греческому Демону. Гений, по мнению римлян, бывает не только у каждого человека, но у каждого семейства, города, страны и т.д. Местных гениев представляли себе в виде змей. В произведениях искусства гении изображаются обыкновенно в виде крылатых существ" $[6$, c. 66]. Кстати, после слова демон у Корша идет отсылка к гению [6, с. 80], что подтверждает заявленную синонимичность античных понятий.

Таким образом, можно утверждать, что мифологема 'гений была принята российским культурным сознанием опосредованно через античность - и потому в исконном смысле существовала в переводных латинских текстах, в заимствованных мифологических образах и персонажах или использовалась в качестве метафоры; актуально же в русскую языковую картину мира вошло толкование гения как самобытного творческого дара в человеке, воплощения высших творческих способностей, вершины человеческого развития, т.е. на стадии идеологизации и ценностной нагруженности понятия ${ }^{1}$. Примеры словоупотреблений 'гений' и “дух в XVIII-XIX вB. показывают, что значения 'творческий дар в человеке' и 'человек, обладающий творческим даром', вытеснили изначальную внутреннюю семантику концепта 'гений'2.

Так, В. В. Виноградов считает, что слово 'гений вошло в русский литературный язык посредством языка масонской литературы. Он называет синонимичные словосочетания "великий дух», «великий гений», поясняя первое выражение вторым: «великий дух (le grand ésprit) в значении 'гений, выдающийся своим творческим дарованием человек” » и, опираясь на тексты Н. М. Карамзина (Предисловие к переводу трагедии Шекспира «Юлий ЦЦезарь» (1787), «Письма русского путешественника» (1791-1792)) и фррагмент письма друга Карамзина - А. А. Петрова, приводит примеры словоупотреблений әения как свойства человеческой природы и как носителя этого свойства. Так, он цитирует авторскую правку

${ }^{1}$ О древнеримских аллюзиях в литературном тексте поговорим ниже. См. примеры из стихотворений В. А.Жуковского.

${ }^{2}$ Неслучайным представляется и тот факт, что среди синонимов слова 'гений' есть относящиеся как к мифологеме ('божество', 'дух', 'покровитель', 'вымышленное существо', 'дар' и др.), так и к идеологемам ('величие', 'дарование', 'сверхталант', 'способность', 'титан мысли' и пр.), в то время как немногочисленные антонимы ('бездарность', 'посредственность'), нужда в которых возникает на более поздней стадии освоения термина, образованы только к семантическим полям 'выдающийся человек', 'талантливый человек'.
Карамзина в «Письмах русского путешественника»: «Сей же дух ревности оживляет и отличает сочинения великих духов" (исправлено: «великих гениев»); приводит мнение Н. Карамзина о Шекспире: «Автор сей жил в Англии во времена королевы Елизаветы и был один из тех великих духов, коими славятся веки», о Клопштоке: «Еще великий муж собою красит мир, // Еще великий дух земли сей не оставил» и о лекции Платнера: «Он говорил о великом духе или о гении. Гений, сказал он, не может заниматься ничем, кроме важного и великого - кроме натуры и человека в целом» [3, с. 303]. К этим примерам использования гения как носителя свойства В. Виноградов добавляет рассуждения упомянутого выше друга Н. Карамзина о гении как свойстве человеческой природы: «Простота чувствования - превыше всякого умничанья; грешно сравнивать натуру, genie, с педантскими подражаниями, с натянутыми подделками низких умов» [3, с. 304]

В 1821 г. в стихотворении «Лалла рук» поэт Василий Андреевич Жуковский использовал слово 'гений скорее в мифологическом значении: «AX! не с нами обитает/Гений чистой красоты;/Лишь порой он навещает/Нас с небесной красоты//OH поспешен, как мечтанье,/Как воздушный утра $\mathrm{coH} / / \mathrm{Ho}$ в святом воспоминанье /Hе разлучен с сердцем он» $[5$, с. 359$]$

Спустя четыре г. Пушкин использует это выражение в своем стихотворении «Я помню чудное мгновенье...» (1825), выделив заимствованное у старшего современника «гений чистой красоты» курсивом, что по традиции тогдашнего написания означало чужое авторство.

Еще один пример присутствия разных семантических полей концепта 'гений” в одном тексте стихотворение Жуковского «К Гете» (1827). Приведем его целиком:

Творец великих вдохновений!

Я сохраню в душе моей

Очарование меновений.

Столь счастливых в близи твоей!

Твое вечернее сиянье

Не о закате говорит!

Ты юноша среди созданья!

Твой гений, как творил, творит.

Я в сердие уноиу надежду

Еще здесь встретиться с тобой

Земле знакомую одежду

Не скоро скинет гений твой.

\section{В далеком полуночном свете \\ Твоею музою я жил. \\ И для меня мой гений Гете \\ Животворитель жизни был!}

Почто судьба мне запретила Тебя узреть в моей весне?

Тогда душа бы воспалила

Свой пламень на твоем огне. 
Тогда б вокруа меня создался

Иной, чудесно-пышный свет;

Тогда б и обо мне остался

В потомстве слух: он был поэт! [5, с. 374]

Интересно это стихотворение именно тем, что актуализирует различные репрезентации мифологемы 'гений', возникавшие на разных этапах ее формирования: гений как свойство человеческой природы, как сопутствующее человеку существо («Твой гений, как творил, творит»; «гений твой) при обращении и Гете); животворная сила («Твое вечернее сиянье/Не о закате говорит!/Ты юноша среди созданья!»; «И для меня мой гений Гете/ Животворитель жизни был»); посредник между небом и людьми - дух, возвращающийся на землю ( «Я в сердце уношу надежду/Еще здесь встретиться с тобой:/Земле знакомую одежду/Не скоро скинет гений твой»); вдохновляющее начало, высшая способность к художественному творчеству («Творец великих вдохновений!); «Тогда душа бы воспалила/Свой пламень на твоем огне»); гений как носитель творческого дара (метонимический перенос свойства на его носителя) - «И для меня мой гений Гете...». Таким образом, в небольшом стихотворении работают семантические поля концепта 'гений” периода от античности до XVIIXVIII вв.

K началу XIX в. в России широко использовалось латинское крылатое выражение Genius loci (Гений места) - добрый гений, дух-покровитель в применении к человеку, ревностно оберегающему неповторимую атмосферу места, обязанного ему своей славой или существованием (переносное значение от исконно римского обозначения доброго духа или гения каждого уголка земли, здания и заведения, в отличие от человеческого, представлявшегося в виде змеи). Интересную информацию находим в статье М. С. Лапиной «`Гению места', или первый памятник А. С. Пушкину»: в середине августа 1817 г. пятеро воспитанников Царскосельского лицея, заручившись согласием директора Е. А. Энгельгардта, установили на холмике возле лицейского флигеля мраморную глыбу, окантованную грубой ковкой, с высеченными и прописанными золотом словами «genio loci» («гению места»). Этот камень, предположительно обработанный знаменитым петербургским камнетесом Самсоном Сухановым, призван был постоянно напоминать лицеистам о том, что здесь расцветал гений их друга Александра Пушкина [7].

В уникальном четырехтомном «Словаре языка Пушкина», выпущенном Государственным издательством иностранных и национальных словарей в 1956 г., гению посвящена исчерпывающе подробная статья, комментирующая не только частотность употребления лексемы гений (всего 122 использования), но и прямые и переносные значения последней в художественном наследии А. С. Пушкина. Так, приводятся пять прямых значений: 1. Статуя, изображающая римское божество - хранителя человека, рода, местности (1) 2. В римской мифологии дух-покровитель чело- века; дух добра и зла (22); 3. Воплощение какого-нибудь идеала душевных свойств человека: высшее проявление чего-нибудь, чего, какой (4); 4. Творческий дар, врожденное дарование, способность к чему-нибудь (58); 5 . Гениальный человек (37). Соответственно, ко второму значению отнесено переносное "дух вдохновения, творчества”; к четвертому - 'высшая творческая одаренность, гениальность' и 'гений кого (отличительные, характерные черты, дух творений какого-нибудь автора)', а к пятому - 'гений чего, в чем (человек, достигший совершенства в каком-нибудь деле) $[25$, с. 467].

В стихотворении А. С. Пушкина «Демон» (1823) (лексема 'демон' употреблена только один раз, в названии) лирический герой вспоминает о печальных встречах, вливавших в душу «хладный яд» в самые прекрасные «часы надежд и наслаждений» - возвышенными чувствами и вдохновенными искусствами: «Тогда какой-то злобный гений/Стал тайно навещать меня/<...> Он звал прекрасное мечтою;/Он вдохновенье презирал;/ Не верил он любви, свободе;/Ha жизнь насмешливо глядел -/И ничего во всей природе/Благословить он не хотел» [13, с. 267]. Драматичная двойственность души художника, горькая, но спасающая от механического восприятия жизни, находит отклик в являющемся ему духе-покровителе, духе добра и зла (второе из перечисленных выше значений гения в наследии Пушкина). Демон и гений, таким образом, употреблены как синонимы.

У М. Ю. Лермонтова, напротив, эти лексемы разведены как антонимы. В стихотворении 1829 г. «К гению» он взывает: «Но я тебя молю, мой неизменный гений:/Дай раз еще любить! Дай жаром вдохновений/Согреться миг один, последний, и тогда/Пускай остынет пыл сердечный навсегда./ $<\ldots>$ Молю тебя, молю, хранитель мой святой, $<\ldots>$ здесь жили вдохновенья!/ <..> хранители души, останьтесь ввек со мною!» [8, с. 27] (гений как творческий дар и как двойник-покровитель). В этом же г. он пишет стихотворение «Мой демон» (переработано в 1830-1831 гг.), органически связанное в пушкинским «Демоном»: «И гордый демон не отстанет, /Пока живу я, от меня, $/ И$ ум мой озарять он станет/Лучом чудесного огня; / Покажет образ совершенства $M$ вдруг отнимет навсегда/ $/$, дав предчувствие блаженства, $/ \mathrm{He}$ даст мне счастья никогда» [8, с. 57] (античный дух-покровитель, дух добра и зла). В 1829-м же г. Лермонтов начал поэму «Демон», законченную только через десять лет. А в 1831-м появилось небольшое стихотворение «Я не для ангелов и рая... ", которое некоторые исследователи считают послесловием к поэме. Здесь падший ангел не просто притягателен в своем трагическом одиночестве, - он - двойник лирического героя: «Как демон мой я зла избранник, /Как демон, с гордою душой, /Я меж людей беспечный странник, /Для мира и небес чужой» $[9$, с. 385].

Наконец, лермонтовский «Ангел» (1831) с наложенным на античную основу христианским по- 
ниманием ближе скорее его же гению, нежели демону: «Он душу младую в объятиях нес/Для мира печали и слез;/ З звук его песни в душе молодой/ Остался - без слов, но живой./М долго на свете томилась она, $/$ Келанием чудным полна; $/ M$ звуков небес заменить не могли/Ей скучные песни земли» $[8$, с. 230].

В русской культурной среде XIX В. вполне привычно существовали многочисленные крылатые выражения европейских авторов с заимствованным из латыни гением ${ }^{1}$ : А. Н. Герцен в письме к Н. Х. Кетчеру в декабре 1835 г. писал по-французски о «неразвившемся гении»: «Ты ничего не сделаешь... и пригодишься только для тени в каком-нибудь романе, ибо... les génies morts en herbe в моде" [См.: 1, с. 46]; в выступлении И. С. Тургенева на открытии памятника Пушкину звучит парафраза приписываемого Мольеру выражения «Гений берет свое добро всюду, где его находит»: «"Le génie prend son bien partout ou il le trouve", - гласит французская поговорка. Независимый гений Пушкина скоро... освободился и от подражания европейским образцам и от соблазна подделки под народный тон» [См.: 1, с. 46]. Попало в российский обиход и приписываемое французскому естествоиспытателю Ж.-Л. Бюффону выражение «Le génie n`est qu`une plus grande aptitude a la patiense» («Гений - это только величайшая способность к терпению») [См.: 1, с. 46].

Просмотр словарных статей «Энциклопедического словаря» Ф. А. Брокгауза и И. А. Ефрона дает представление о степени 'вписанности' лексемы 'гений' в русскую языковую картину мира к рубежу XIX-XX вв., более того - о представленности в последней концепта 'гений': как ядра, так и его периферии. Интересно, что ми- фологическое значение ('внутренняя форма') репрезентируется здесь только в статьях о персонажах античных мифов или об их воплощении в художественных образах последующих эпох (Гуан-ди - 'гений-хранитель' манчжурской династии; Вирбий - древнеитальянский демон, гений леса и охоты; статуя Мерсье «Гений искусства на Пегасе» и пр.). В остальных случаях наблюдаем идеологемы, отпочковавшиеся от мифологемы гения в Новое время: 'гений' 1) как синоним олицетворения, воплощения первооснов, добрых и злых, т.е. 'дух', но уже не в прямом, а в переносном смысле (название журнала Н. И. Греча «Гений времен», 1807-1809); 2) как свойство природы человека (драматический гений Пушкина; гений Бетховена; военный гений Наполеона; гений Рафаэля; гений Глинки; гений греков; стихийность гения Байрона); 3) как носитель этого свойства (три величайших гения живописи - Леонардо да Винчи, Микеланджело и Рафраэль; Наполеон как первоклассный военный гений; название произведения шведского дипломата и поэта Брикмана «Мир гения»; характеристика талантливого человека: «от гения отличается меньшей степенью творческой оригинальности»; название драмы Дюма-отца «Кин, или гений и беспутство»).

Таким образом, можно утверждать, что лексема гений, принятая российским культурным сознанием в XVIII в. и, в ответ на вызовы времени обраставшая новыми смыслами, стала ядром одноименного концепта со множеством семантических полей, что совпадает с общеевропейским формированием концепта и свидетельствует о значительных трансформациях национальной, научной и художественной картины мира в отечественном культурном пространстве.

\section{Литература}

1. Бабкин А. М., Шендецов В. В. Словарь иноязычных выражений и слов, употребляющихся в русском языке без перевода: В 2 т. Т.1. М.-Л.: Наука, 1966. 712 с.

2. Брокгауз Ф. А., Ефрон И. А. Энциклопедический словарь. Т.8. Спб.: Типо-Литография И. А. Ефрона, 1892.478 С.

3. Виноградов В. В. Проблема авторства и теория стилей. М.: ГИХЛ, 1961. 614 с.

4. Даль В. И. Толковый словарь живого великорусского языка: В 4 т. Т.1. М.: Русский язык, 1989. 700 с.

5. Жуковский В. А. Собрание сочинений: В 4 т. Т.1. М.-Л.: Художественная литература, 1959. 480 с.

6. Корш М. Краткий словарь мифологии и древностей. СПб.: Изд. А.С. Суворина, 1894. 252 с.

7. Лапина М. С. «Гению места», или первый памятник А.С.Пушкину // Наука и жизнь. 1999. №11. С. 11-13

8. Лермонтов М. Ю. Полное собрание сочинений (далее - ПСС): В 6 т. Т.1. М.-Л.: Изд. АН СССР, 1954. 452 с

9. Лермонтов М. Ю. ПСС: В 6 т. Т.4. М.-Л.: Изд. АН СССР, 1955. 428 с.

10. Материалы для словаря древнерусского языка по письменным памятникам. Труд И. И. Срезневского. Т.1. СПб.: Типогр. Импер. АН, 1983. 793 с.

11. Михельсон А. Д. 30000 иностранных слов, вошедших в употребление в русский язык, с объяснением их корней По словарям: Гейзе, Рейфа и др. М.: Собств. изд. автора, 1866. 771 с.

12. Попов М. Полный словарь иностранных слов, вошедших в употребление в русском языке. М.: Т-во И.Д.Сытина 1907. $458 \mathrm{c}$.

13. Пушкин А.С. ПСС: в 17 т. Т.2 (кн.1). М.: Воскресенье, 1994. 568 с.

14. Семенов А. В. Этимологический словарь русского языка. Русский язык. от А до Я. Москва: ЮНВЕС, 2003. 704 с.

15. Словарь древнего славянского языка, составленный по Остромирову евангелию. СПб.: Изд. А. С. Суворина 1899. $946 \mathrm{c}$.

16. Словарь иностранных слов, вошедших в состав русского языка / сост под ред. Ф. Н. Берга. Издание А. А. Петровича. М.: Кушнер и К우 1901.752 с.

\footnotetext{
1 Французское и немецкое genie, genial; английское genius; испанское genio.
} 
17. Словарь иностранных слов, вошедших в состав русского языка / сост. по Энциклопед. слов. Ф. Павленкова с соответствующими сокращениями в объяснении слов и добавлении в их числе. 2-е изд. СПб.: Изд. Ф. Павленкова, 1907. $714 \mathrm{c}$.

18. Словарь иностранных слов, вошедших в состав русского языка. Материалы для лексической разработки заимствованных слов в русской литературной речи. Изд. З-е. / под ред. А. Н. Чудинова. СПб.: Изд. В. И. Губинского, 1910. $676 \mathrm{c}$.

19. Словарь иностранных слов. «60000» вошедших в употребление в русском языке с обозначением их корней / сост. Бурдон и Михельсон. М.: Изд. С. И. Леухина, 1880. 854 с.

20. Словарь иностранных слов, наиболее употребительных в русском языке (Сост. Под ред. М.3-ского). Киев: [б.и.], 1891. $351 \mathrm{c}$.

21. Словарь иностранных слов, употребительных в русской литературе. М.: Типография К. Андерса, 1861.77 с.

22. Словарь русского языка XVIII вв. Вып.5. Л.: Наука, 1989. 256 с.

23. Словарь современного русского литературного языка: Т.З. М.-Л.: Издательство АН СССР, 1954.1340 с.

24. Словарь церковно-славянского и русского языка, составленный ІІ отделением Импер. АН. Т.1. СПб.: Тип. Импер. $\mathrm{AH}, 1847.415 \mathrm{c}$.

25. Словарь языка Пушкина: В 4 т. Т.1. М.: Гос. изд. иностр. и нац. словарей, 1956. 807 с.

26. Смирнов Н. А. Западное влияние на русский язык в Петровскую эпоху. СПб.: Тип. АН, 1910.384 с.

27. Соколов П. И. Общий церковно-славяно-российский словарь. СПб.: Тип. Рос. акад., 1834. 883 с.

28. Фасмер М. Этимологический словарь русского языка. Т.1. Под ред. Б. А. Ларина. М.: Прогресс, 1986.576 с

29. Черных П. Я. Историко-этимологический словарь современного русского языка: В 2 т. Т.1. М.: Рус. яз., 1999. $623 \mathrm{c}$.

30. Этимологический словарь русского языка / под ред. Н. М. Шанского. Т.1. Вып.4. М.: МГУ, 1972.215 с.

\section{References}

1. Babkin A. M., Shendetsov V. V. Slovar' inoyazychnykh vyrazhenii i slov, upotreblyayushchikhsya v russkom yazyke bez perevoda (The Dictionary of Foreign-Language Expressions and Words Which are Used in Russian Without Translation): In 2 Vols. Vol.1. Moscow - Leningrad: Nauka, 1966. 712 p. (In Russian).

2. Brokgauz F. A., Efron I. A. Entsiklopedicheskii slovar (Encyclopedic Dictionary). Vol.8. St.Petersburg: I. A. Efron's printing house, 1892. 478 p. (In Russian).

3. Vinogradov V. V. Problema avtorstva i teoriya stilei (Problem of Authorship and Theory of Styles). Moscow: GlKhL, 1961. 614 p. (In Russian).

4. Dal' V. I. Tolkovyi slovar' zhivogo velikorusskogo yazyka (Explanatory Dictionary of Living Great Russian Language): In 4 Vols. Vol.1. Moscow: Russkii yazyk, 1989. 700 p. (In Russian).

5. Zhukovskii V. A. Sobr. soch. (Collected Works): In4 Vols. Vol.1. Moscow - Leningrad: Khudozh. lit., 1959. (In Russian).

6. Korsh M. Kratkii slovar' mifologii i drevnostei (Concise dictionary of Mythology and Antiquities). St.Petersburg A. S. Suvorin' publishisng house, 1894. 252 p. (In Russian).

7. Lapina M. S. "Geniyu mesta», ili pervyi pamyatnik A. S. Pushkinu (To "TheGenius of Place", or First Monument to A. S. Pushkin) // Nauka i zhizn'. 1999. No.11. P. 11-13. (In Russian).

8. Lermontov M. Yu. PSS (Complete Works). In 6 Vols. Vol.1. Moscow - Leningrad: SA USSR publ., 1954. 452 p. (In Russian).

9. Lermontov M. Yu. (PSS) (Complete Works). In 6 Vols. Vol. 4. Moscow - Leningrad: SA USSR publ., 1956. 428 p. (In Russian).

10. Materialy dlya slovarya drevnerusskogo yazyka po pis'mennym pamyatnikam (Materials for the Dictionary of Old Russian Language on Written Monuments). Vol.1. St.Petersburg, 1983. 793 p. (In Russian).

11. Mikhel'son A. D. 30000 inostrannykh slov, voshedshikh $v$ upotreblenie $v$ russkii yazyk, s ob»yasneniem ikh kornei (30000 Foreign Words Which Have Come into Use in Russian with an Explanation of Their Roots). Moscow, 1866. 771 p. (In Russian).

12. Popov M. Polnyi slovar' inostrannykh slov, voshedshikh v upotreblenie v russkom yazyke (The Unabridged Dictionary of the Foreign Words Which Have Come into Use in Russian). Moscow: I. D. Sytin's partnership, 1907. 458 p. (In Russian).

13. Pushkin A. S. PSS: v 17 t. (Complete Works: In 17 Volumes). Vol. 2 (Book.1). Moscow: Voskresen'e, 1994. 568 p. (In Russian).

14. Semenov A. V. Etimologicheskii slovar' russkogo yazyka. Russkii yazyk. ot A do Ya (Etymological Dictionary of Russian. Russian. from A to Z). Moscow: YuNVES, 2003.704 p. (In Russian).

15. Slovar' drevnego slavyanskogo yazyka, sostavlennyi po Ostromirovu evangeliyu (The Dictionary of Classic Slavionic Language Made According to the Ostromir Gospels). St. Petersburg: A. S. Suvorin' publishisng house, 1899. 946 p. (In Russian).

16. Slovar' inostrannykh slov, voshedshikh v sostav russkogo yazyka (The Dictionary of the Foreign Words Which Have Been a Part of Russian)/ ed by F. N. Berg. Moscow: Kushner i Ko, 1901. 752 p. (In Russian).

17. Slovar' inostrannykh slov, voshedshikh v sostav russkogo yazyka (The Dictionary of the Foreign Words Which Have Been a Part of Russian). St. Petersburg: F. Pavlenkov, 1907. 714 p. (In Russian).

18. Slovar' inostrannykh slov, voshedshikh v sostav russkogo yazyka. Materialy dlya leksicheskoi razrabotki zaimstvovannykh slov v russkoi literaturnoi rechi (The Dictionary of the Foreign Words Which Have Been a Part of Russian. Materials for Lexical Development of Loan Words in the Russian Literary Speech) / ed by A. N. Chudinov. St.Petersburg: V.I.Gubinskii, 1910. 676 p. (In Russian).

19. Slovar' inostrannykh slov. «60000» voshedshikh v upotreblenie v russkom yazyke s oboznacheniem ikh kornei (Dictionary of Foreign Words. "60000" Their Roots Which Have Come into Use in Russian with Designation). Moscow: S.I.Leukhin, 1880. 854 p. (In Russian). 
20. Slovar' inostrannykh slov, naibolee upotrebitel'nykh v russkom yazyke (Dictionary of Foreign Words. "60000" Their Roots Which Have Come into Use in Russian with designation). Kiev, 1891. 351 p. (In Russian).

21. Slovar' inostrannykh slov, upotrebitel'nykh v russkoi literature (The Dictionary of Foreign Words, Common in Russian Literature). Moscow: K.Anders, 1861. 77 p. (In Russian).

22. Slovar' russkogo yazyka XVIII vv. (Dictionary of Russian of the 18th Century). Issue 5. Leningrad: Nauka, 1989. 256 p. (In Russian).

23. Slovar' sovremennogo russkogo literaturnogo yazyka (Dictionary of the Modern Russian Literary Language): Vol.3. Moscow - Leningrad: SA USSR, 1954. 1340 p. (In Russian).

24. Slovar' tserkovno-slavyanskogo i russkogo yazyka, sostavlennyi II otdeleniem Imper. AN (The Dictionary Church Slavonic and Russian, Made by the // office of Imperial Academy of Sciences). Vol.1. St.Petersburg, 1847. 415 p. (In Russian) 25. Slovar' yazyka Pushkina (Dictionary of Pushkin's Language): In 4 Vols. Vol.1. Moscow, 1956. 807 p. (In Russian).

26. Smirnov N. A. Zapadnoe vliyanie na russkii yazyk v Petrovskuyu epokhu (The Western Influence on Russian during the Petrovsky Era). St.Petersburg, 1910. 384 p. (In Russian).

27. Sokolov P. I. Obshchii tserkovno-slavyano-rossiiskii slovar (The General Church-Slavonic-Russian Dictionary). St.Petersburg, 1834. 883 p. (In Russian).

28. Fasmer M. Etimologicheskii slovar' russkogo yazyka (Etymological Dictionary of Russian). Vol .1 / ed. by B. A. Larin. Moscow: Progress, 1986. 576 p. (In Russian).

29. Chernykh P. Ya. Istoriko-etimologicheskii slovar' sovremennogo russkogo yazyka (Historical and Etymological Dictionary of Modern Russian) In 2 Vols. Vol.1. Moscow: Rus. yaz., 1999. 623 p. (In Russian).

30. Etimologicheskii slovar' russkogo yazyka (Etymological Dictionary of Russian) / ed by N. M. Shanskii. Vol.1. Issue.4 Moscow: MSU publ., 1972. 215 p. (In Russian). 